\title{
In defense of four decades of esophageal function tests. Reply to reaction to articles on high resolution manometry, the length of the lower esophageal sphincter and the diagnosis of gastroesophageal reflux disease
}

\author{
Fernando A M HERBELLA, Rogério Mariotto Bitetti da SILVA and Leonardo M Del GRANDE
}

\section{Dear Editor,}

Esophageal function tests are in current clinical use since the 1970ies. The management of gastroesophageal reflux disease and other esophageal motility disorders is highly dependent on these tests. We thank Dr. Levin for his interest in two of our studies ${ }^{(1,2)}$. We were thrilled with his disapproval of current methods to evaluate esophageal physiology. We read with curiosity his criticisms in the expectation of being educated on better alternatives to current methods but unfortunately they were not provided and, unfortunately again, his publications are available only in Russian language and local journals. In response to his questions:

First, individuals that volunteered to both studies were indeed selected by the absence of symptoms. This was justified by two reasons: (1) we considered not necessary or ethical to submit these individuals to upper endoscopy and (2) the mathematics for the determination of cut-off values consider the chance to accidentally include sick individuals. We did not adopt as threshold the minimum and maximum values found in the tests but the 5 th and 95 th percentile. In few words, $10 \%$ of the population was excluded based on the outliers. Moreover, the same methodology was applied in the landmark studies that defined normal values worldwide accepted, such as the Richter et al. ${ }^{(3)}$ study that defined values for conventional manometry, the Northwestern studies that defined the Chicago classification ${ }^{(4)}$ and the Johnson and DeMeester study that defined normality for $\mathrm{pH}$ monitoring ${ }^{(5)}$. In regards to histological analysis, the routine biopsy of the esophagus in negative endoscopy is not recommended by any consensus including the Montreal ${ }^{(6)}$, Lyon $^{(7)}$ and Porto ${ }^{(8)}$.
Second, we are unfamiliar with any extraluminal technique to measure esophageal motility. We hope Dr. Levin can educate us in future studies.

Third, we did find, together with other authors, the 'absurd' result that thoracic pressure is inferior to abdominal pressure. This transdiaphragmatic pressure gradient is well-known since the primordial days of esophageal physiology ${ }^{(9)}$. The statement that 'If this study is correct, then during the opening of the LES, the bolus should move in a retrograde direction - from the stomach into the esophagus' is absolutely correct, unless a valve is interposed between the thorax and the abdomen (what happens in the basal state) or peristalsis pushes bolus down (what happens during swallows). The failure of peristalsis or the valvar mechanism or increase in the pressure gradient is actually the pathophysiology of gastroesophageal reflux disease $\mathrm{e}^{(10)}$.

Dr. Levin is once more correct when he says that 'it is necessary to start a broad discussion in order to choose rational methods of scientific research and diagnostics of diseases of the esophagus and the gastroesophageal junction' but for this a profound knowledge of what is already known about esophageal diseases is mandatory.

\section{Orcid}

Fernando A M Herbella. Orcid: 0000-0003-3594-5744.

Rogério Mariotto Bitetti da Silva. Orcid: 0000-0003-2988-9061. Leonardo M Del Grande. Orcid: 0000-0001-7115-1218. 


\section{REFERENCES}

1. Silva RMBD, Herbella FAM, Gualberto D. Normative values for new water-perfused high resolution manometry system. Arq Gastroenterol. 2018;55 (Suppl 1):30-4

2. Del Grande LM, Herbella FAM, Katayama RC, Schlottmann F, Patti MG. The role of the transdiaphragmatic pressure gradient in the pathophysiology of gastroesophageal reflux disease. Arq Gastroenterol. 2018;55 (Suppl 1):13-7.

3. Richter JE, Wu WC, Johns DN, Blackwell JN, Nelson JL 3rd, Castell JA, Castell DO. Esophageal manometry in 95 healthy adult volunteers. Variability of pressures with age and frequency of "abnormal" contractions. Dig Dis Sci. 1987;32:583-92.

4. Ghosh SK, Pandolfino JE, Zhang Q, Jarosz A, Shah N, Kahrilas PJ. Quantifying esophageal peristalsis with high-resolution manometry: a study of 75 asymptomatic volunteers. Am J Physiol Gastrointest Liver Physiol. 2006;290:G988-97.

5. Johnson LF, Demeester TR. Twenty-four-hour pH monitoring of the distal esophagus. A quantitative measure of gastroesophageal reflux. Am J Gastroenterol. 1974;62:325-32.
6. Vakil N, van Zanten SV, Kahrilas P, Dent J, Jones R; Global Consensus Group The Montreal definition and classification of gastroesophageal reflux disease: a global evidence-based consensus. Am J Gastroenterol. 2006;101:1900-20 quiz 1943

7. Gyawali CP, Kahrilas PJ, Savarino E3, Zerbib F, Mion F, Smout AJPM, Vaezi M, Sifrim D, Fox MR, Vela MF, Tutuian R, Tack J, Bredenoord AJ, Pandolfino J, Roman S. Modern diagnosis of GERD: the Lyon Consensus. Gut. 2018;67:1351-62.

8. Sifrim D, Castell D, Dent J, Kahrilas PJ. Gastro-oesophageal reflux monitoring review and consensus report on detection and definitions of acid, non-acid, and gas reflux. Gut. 2004;53:1024-31.

9. DeMeester TR, Wernly JA, Bryant GH, Little AG, Skinner DB. Clinical and in vitro analysis of determinants of gastroesophageal competence. A study of the principles of antireflux surgery. Am J Surg. 1979;137:39-46.

10. Menezes MA, Herbella FAM. Pathophysiology of Gastroesophageal Reflux Disease. World J Surg. 2017;41:1666-71. 